\title{
Kosova'da Kullanılan 6. Sınıf Türkçe Ders Kitabının Türkçe Öğretim Programı ve Yenilenmiş Bloom Taksonomisi Açısından Değerlendirilmesi*
}

\section{Evaluation of 6th Grade Turkish Textbooks Used in Kosovo in Terms of Turkish Education Program and Revised Bloom Taxonomy}

\section{Necati Demir, Ramazan Eryılmaz}

\begin{tabular}{l} 
Yazar Bilgileri \\
\hline Necati Demir \\
Prof. Dr., Gazi Üniversitesi, \\
Gazi Eğitim Fakültesi, Türkçe \\
Eğitimi, \\
necatidemir@gazi.edu.tr \\
Ramazan Eryılmaz \\
Dr., Öğretmen, Millî Eğitim \\
Bakanlığı, \\
ramazan.eryilmaz@gazi.edu.tr
\end{tabular}
ÖZ

Çalışmanın amacı, Kosova'da kullanılan 6. sınıf Türkçe Ders Kitabı'nın öğretim programı kazanımları ve bilişsel alan basamakları açısından incelenmesidir. Araştırma, nitel araştırma yöntemlerinden durum çalışması olarak desenlenmiştir. Verilerin toplanması sürecinde, doküman incelemesi yöntemi kullanılmıştır. İncelenen dokümanlar, Kosova Alt Ortaöğretim Altıncı Sınıf Plan ve Programı ile 6. sınıf Türkçe Ders Kitabıdır Verilerin analizinde Yenilenmiş Bloom Taksonomisi esas alınmıştır. Bulgulara göre ders kitabında, programda öngörülen 26 kazanımdan; 18'i bulunmakta, 8'i bulunmamaktadır. Metin altı sorularında alt düzey bilişsel süreç basamaklara ağırlık verilmekte, bilgi türlerinden olgusal bilgi yoğunluk göstermektedir. Ulaşılan sonuçların alanyazın ışığında yorumlanması sonucunda Kosova'da kullanılan 6. sınıf Türkçe Ders Kitabı'nın öğretim programı kazanımlarını yansıtma ve bilişsel alan basamaklarının dengeli dağılması anlamında yetersiz olduğu değerlendirilmiştir. Kitap yazım sürecinde ve yeni baskılarda çalışma sonuçlarının göz önünde bulundurulması önerilmektedir.

\begin{tabular}{|c|c|}
\hline Makale Bilgileri & ABSTRACT \\
\hline $\begin{array}{l}\text { Anahtar Kelimeler } \\
\text { Kosova } \\
\text { Türkçe } \\
\text { Ders Kitabı } \\
\text { Öğretim Programı } \\
\text { Bloom Taksonomisi } \\
\text { Keywords } \\
\text { Kosovo } \\
\text { Turkish } \\
\text { Textbook } \\
\text { Teaching Program } \\
\text { Bloom Taxonomy }\end{array}$ & $\begin{array}{l}\text { The aim of the study is to examine the 6th-grade Turkish Textbook used in Kosovo as an } \\
\text { important element of the Turkish lesson and the most important lesson material, in terms } \\
\text { of the learning program outcomes and cognitive domain steps. The research was designed } \\
\text { as a case study from qualitative research methods. During the data collection process, the } \\
\text { document analysis method was used. The documents reviewed are the Kosovo Lower } \\
\text { Secondary Education Sixth Grade Plan and Program and the 6th-grade Turkish Textbook. } \\
\text { The Revised Bloom Taxonomy was used in the analysis of the data. According to the } \\
\text { findings, } 18 \text { of the } 26 \text { acquisitions predicted in the curriculum exist in the textbook, while } \\
\text { the remaining eight do not. In the sub-text questions, the lower level cognitive process } \\
\text { steps are emphasized, and the factual knowledge is concentrated among the types of } \\
\text { knowledge. According to the data of the literature and the results reached, the textbook is } \\
\text { insufficient in terms of fulfillment of the objectives and the balanced distribution of the } \\
\text { cognitive domain steps. It is recommended to consider the result of the study in the book } \\
\text { writing process and new editions. }\end{array}$ \\
\hline
\end{tabular}

Makale Geçmişi

Geliş: 30.10.2020

Düzeltme: 21.02.2021

Kabul: 24.02 .2021

*Bu araştırma birinci yazar danışmanlığında ikinci yazar tarafından yürütülen doktora tezinden üretilmiştir. 


\section{Giriş}

Türkçe eğitimi yalnızca Türkiye'de yürütülen bir faaliyet olarak değerlendirilmemelidir. Türkiye dışında birçok ülkede ana dilinde Türkçe eğitim yapılmaktadır. Türkçe eğitiminin hedef kitlesi bakımından bir sınıflamaya gidildiğinde; Türkiye Türkleri, iki dilliler, yabancılar ve Türk soylular olmak üzere dört ana grup ortaya çıkmaktadır (Duman, 2003; Şen, 2010). Demir (2014), buna Balkanlarda Osmanlı Döneminden kalma Türklere Türkçe öğretimini de eklemektedir (s. 19-33). Bu son grup, iki dilliler başlığı altında değerlendirilebilir. Türkçe eğitiminde iki dilliler; her ne kadar Türk soylu olsalar da toplumsal ve siyasal koşullar gereği Türkçe dışında başka dilleri de ana dili seviyesinde konuşan öğrencileri ifade etmektedir. Balkan bölgesi ülkelerinde, Türkler azınlı statüsünde olmaları dolayısıyla, yaşadıkları ülkelerin şartları ve yasaları uyarınca Türkçe eğitim görebilmektedirler. Bu ülkelerde kullanılan Türkçe ders kitaplarının, Türkiye'den gönderilmesi söz konusu olmamakta; eğer varsa ülkenin eğitim bakanlığı tarafından basılmış kitaplar kullanılmaktadır (Kayadibi, 2017; Kelağa, 2005; Kurt, 2017). Bu ülkelerden biri olan Kosova'da azımsanmayacak sayıda öğrenci ana dilleri olan Türk dilinde eğitim almaktadır. 2018 yılı istatistiklerine göre Kosova'da devlet okullarında Türkçe anadilinde eğitim alan öğrenci sayısı 3000'e yaklaşmaktadır. Ortaokul seviyesinde eğitim alan 963 öğrenci kayda geçmiştir (Kosovo Agency of Statisctics, 2018). Ortaokul kademesi Kosova'daki karşılığıyla alt ortaöğretim - 6, 7, 8 ve 9. sınıf seviyelerinden oluşmakta fakat bunlardan sadece 6. ve 7. sınıfların Türkçe ders kitapları bulunmaktadır.

Türkçe eğitiminde en önemli ders materyali halâ ders kitabıdır. Kosova Türk toplumu için başarılı bir Türkçe eğitimi, toplumsal ve dilsel bütünlük ve uyum için gereklidir. Bunun için en önemli ders materyali olarak ders kitabının incelenmesi hem Türkçe öğretim planı geliştirme hem de ders kitabı yazma sürecine dönük yapıcı eleştiriler ve dönütler sağlanması adına önemlidir. Yapılan alan yazın taramasında, Kosova'da ortaokul seviyesinde kullanılan Türkçe ders kitaplarının incelendiği bir çalışma tespit edilmemiştir. Bu açıdan Kosova'da kullanılan, 6. sınıf Türkçe Ders Kitabı'nın verimliliğini etkileyecek bir unsur olarak geri bildirimden yoksun olması çalışmanın problem durumu olarak ortaya çıkmaktadır.

Ders kitabının hazırlanmasında ilgili öğretim programının belirleyici olması ve bu kitabın içeriğinin oluşturulmasında Bloom taksonomisinin temel alınması dolayısıyla kitabın değerlendirilmesinde bu iki etkenin göz önünde tutulmasının uygun olacağı kanaati oluşmuştur (Eryılmaz, 2020). Bundan hareketle çalışmanın amacı, 6. sınıf Türkçe Ders Kitabı'nın (Sülçevsi ve Sülçevsi, 2007) öğretim planı kazanımları ve bilişsel alan basamakları açısından değerlendirilmesidir (Anderson ve Krathwohl, 2001; Kosova Eğitim Bilim ve Teknoloji Bakanlığı, 2003).

Çalışmada bulgularının düzenliliği ve daha ayrıntılı sonuçlar elde etmek adına alt sorun cümleleri belirlenmiştir: 
1. 6. sınıf Türkçe Ders Kitabı'nda Kosova Alt Ortaöğretim 6. sınıf Türkçe Öğretim Plan ve Programı kazanımları ne kadar yer bulmuştur?

2. 6. sınıf Türkçe Ders Kitabı metin altı sorularının bilişsel alan basamakları bakımından durumu nedir?

Çalışmanın kuramsal çerçevesi içinde bazı kavram ve durumları daha yakından incelemek gerekmektedir. 6. sınıf Türkçe Ders Kitabı'nın hazırlanmasında temel teşkil eden öğretim programı (Kosova Eğitim Bilim ve Teknoloji Bakanlığı, 2003), metin altı sorularının ve alıştırmaların tasarlanmasında esas alınan Bloom'un bilişsel alan basamakları bu bağlamda ele alınmıştır.

\section{Kosova Türkçe Öğretim Programı ve 6. Sınıf Türkçe Ders Kitabı'nda Konu ve Metin Dağılımı}

Kosova'daki bir takım siyasi gelişmelerden sonra bağımsız Kosova devleti kurulmuş; bu ülkedeki Türkçe eğitim tarihinde, devlet denetiminde ilk Türkçe programı 2003 yılında hazırlanmaya başlamıştır. Kosova'nın Eğitim Bilim ve Teknoloji Bakanlığı bünyesinde bu ülkeden yaşayan Türk, Türk Dili uzmanları ve Türkçe öğretmenlerinin de katıldığı bir program geliştirme süreci yürütülmüştür. Kosova'da ortaokul seviyesi, alt ortaöğretim olarak ifade edilmekte; alt ortaöğretim 6., 7., 8. ve 9. siniflardan meydana gelmektedir.

Kosova'da Türkçe öğretim programları 6., 7., 8. ve 9. sınıflar için ayrı ayrı hazırlanmıştır. Örneğin 6. sınıflar için hazırlanan program, Alt Ortaöğretim Altıncı Sınıf Öğretim Plan ve Programı adıyla yayımlanmıştır (Kosova Eğitim Bilim ve Teknoloji Bakanlığı 2003). Ortaya çıkan programlar temel alınarak, Türkçe Öğretim Programı Komisyonu tarafından yazılan Türkçe ders kitaplarının basımı için 2006 yılında ihaleler yapılmıştır. 2007 yılında 6. Sınıf Türkçe Ders Kitabı'nın, 2009 yılında da 7. Sınıf Türkçe Ders Kitabı'nın basımı yapılmıştır (Eryılmaz, 2020; Koro, 2013).

İnceleme nesnesinin 6. Sınıf Türkçe Ders Kitabı olması dolayısıyla Alt Ortaöğretim Altıncı Sınıf Öğretim Plan ve Programı́nın (Kosova Eğitim Bilim ve Teknoloji Bakanlığı, 2003) daha ayrıntılı ele alınması gerekmektedir. Bu programın ana başlıkları: Genelge, Giriş, Hedefler/Kazanımlar, Değerlendirme, Öğretim Araç ve Gereçleri, Ders Planı Ders Süreci, Öğretim Yöntem ve Teknikleri şeklinde ortaya çıkmaktadır (Kosova Eğitim Bilim ve Teknoloji Bakanlığı, 2003). Programın (2003) Hedefler bölümünde yer alan kazanımlar Tablo 1'de görülmektedir.

6. Sınıf Türkçe Ders Kitabı ünitelerden oluşmaktadır. Her ünitede aynı şablon kullanılmıştır. Şekil 1'de görülmektedir.

Tablo 1. Kosova Alt Ortaöğretim 6. Sınıf Türkçe Öğretim Programı Kazanımları

\begin{tabular}{|c|c|}
\hline Alan & Kazanım \\
\hline \multirow{4}{*}{ 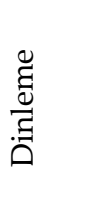 } & 1. Karşısındakinin sözünü kesmeden dinleyebilme \\
\hline & $\begin{array}{l}\text { 2. Kelime hazinesini, genel kültürünü ve iç dünyasını zenginleştirip çeşitlendirecek yayın, film } \\
\text { ve konferansları izleyebilme }\end{array}$ \\
\hline & 3. Sesli ve sessiz okuma hızını arttırma ve tekniğini kusursuz duruma getirme \\
\hline & 4. Dinlediklerinin ve izlediklerinin ana fikrini kavrayabilme \\
\hline
\end{tabular}




\begin{tabular}{|c|c|}
\hline \multirow{5}{*}{ 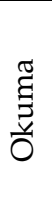 } & 5. Yeni öğrenilmiş kelime, kelime grubu, deyim, atasözü anlamlarını kavrayabilme \\
\hline & 6. Düzyazı veya şiirin oluşturulma planını çıkarabilme \\
\hline & 7. Okuduklarının şekil ve içerik özelliklerini kavrayabilme \\
\hline & 8. Okuduklarını muhteva açısından anlayabilme \\
\hline & 9. Seçilen bir parçayı tonlamayı ve vurguyu uygulayarak ve canlandırma ile okuyabilme \\
\hline \multirow{2}{*}{ 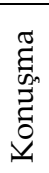 } & 10. Düşünce, arzu ve isteklerini düzgün, belli bir süre içinde ve planlı bir şekilde anlatabilme \\
\hline & $\begin{array}{l}\text { 11. Günlük yaşantılarını selamlaşmaları ve özür ifadelerini her ortamda görgü kurallarına } \\
\text { uygun bir şekilde dile getirebilme }\end{array}$ \\
\hline \multirow{3}{*}{ 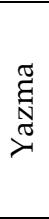 } & $\begin{array}{l}\text { 12. Yazım ve sözdizimi yanlışı yapmadan yazabilme, noktalama işaretlerini yerinde } \\
\text { kullanabilme }\end{array}$ \\
\hline & $\begin{array}{l}\text { 13. Düşünce, arzu ve isteklerini düzgün, belli bir süre içinde ve planlı bir şekilde yazıya } \\
\text { aktarabilme }\end{array}$ \\
\hline & 14. Resmi yazışmaları öğrenme \\
\hline \multirow{9}{*}{ 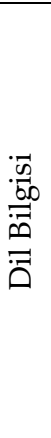 } & 15. Kelimelerin değişik anlamlarını kavrayabilme \\
\hline & 16. Sesteş, anlamdaş, zıt anlamlı kelimeleri kullanabilme \\
\hline & 17. Ünlü uyumlarını kavrayıp uygulayabilme \\
\hline & 18. Kelime türlerini cümle içindeki anlam ve görevlerine göre tanıma ve kullanabilme \\
\hline & 19. Kelime yapısı ve türetme yollarını kavrayabilme \\
\hline & 20. Noktalama işaretlerini doğru kullanabilme \\
\hline & 21. Eylem kiplerini ve çatılarını, birleşik eylem, eylemsileri kavrama \\
\hline & $\begin{array}{l}\text { 22. Cümle ögelerinin sıralanışını, sıralanışa göre anlam değişikliğini kavrayıp cümleyi buna } \\
\text { göre kurma }\end{array}$ \\
\hline & 23. Cümle türlerini öğrenebilme \\
\hline
\end{tabular}

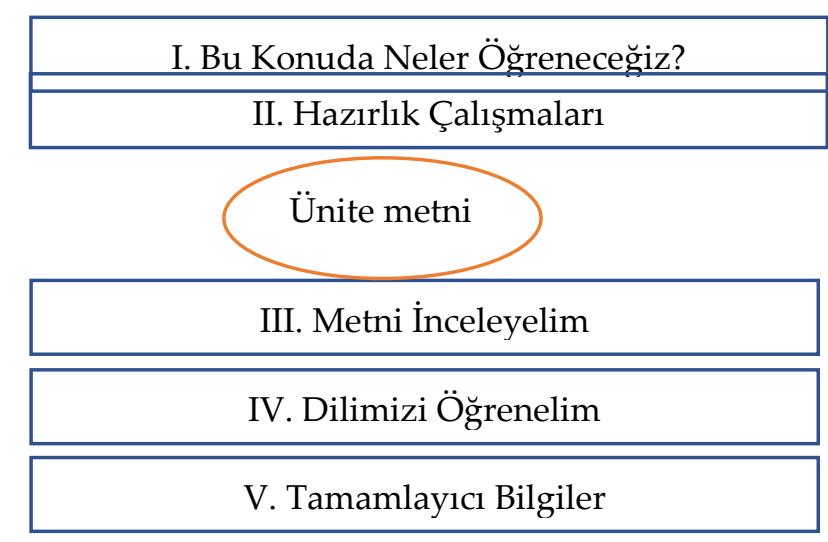

Şekil 1. 6. Sınıf Türkçe Ders Kitabı'nın Ünite Şablonu Sülçevsi, İ., \& Sülçevsi, N. (2007). Türkçe 6. Priştine: Albas.

Tablo 2. 6. Sinıf Türkçe Ders Kitabı Konu Dağılımı

\begin{tabular}{|c|c|c|}
\hline Metin & Dilimizi Öğrenelim & Tamamlayıcı Bilgiler \\
\hline 1. & Görülen geçmiş zaman & $\begin{array}{l}\text { Görülen geçmiş zamanın olumsuz ve soru } \\
\text { biçimi }\end{array}$ \\
\hline 2. & Karşıt anlamlı sözcükler & Karşıt anlamlı sözcükler \\
\hline 3. & Şimdiki zaman kipi & Büyük ünlü uyumuna aykırı haller \\
\hline 4. & Türkiye Türkçesi ve Kosova Ağzı & Fablın özellikleri \\
\hline 5. & Deyimler, Düzeltme işaretinin kullanımı & Tekerlemeler \\
\hline 6. & Sifatlar & Sıfatların kullanımı \\
\hline 7. & Adlar ve çeşitleri, Belirtme sıfatları & Kafiye \\
\hline 8. & Soru işareti, ünlem işareti, tırnak işareti & Kosova'da tırnak işareti kullanımı \\
\hline 9. & Noktalama işaretleri, Geniş zaman & Evliya çelebinin hayatı ve eserleri \\
\hline 10. & Türkçenin hece yapısı & Atatürk'ün hayatı \\
\hline
\end{tabular}




\begin{tabular}{lll}
\hline 11. & Tasarlama kipleri & Hece ölçüsü \\
12. & Öge dizilişine göre cümle çeşitleri & Naim Frasheri'nin hayatı ve eserleri \\
13. & Öğrenilen geçmiş zaman & Okuma çeşitleri \\
14. & Soru edatının yazımı & Adlarda çokluk \\
15. & Durum ekleri & Tiyatro \\
16. & Gelecek zaman eki & Efsane \\
17. & Ünlüler ve büyük ünlü uyumu & Ünlülerin özellikleri \\
18. & Hikâyede zaman & Ek eylemin kiplere göre çekimi \\
19. & Ek eylem, İsim fiil & Kişi ekleri \\
20. & Bildirme kipleri Dilek kipleri & Dilekçe yazımı \\
21. & “de” “da” bağlacının yazımı & “ki” bağlacının yazımı \\
22. & Zamirler & Otobiyografi, biyografi \\
23. & Türkçede ünsüzlerin özellikleri & Sözlük kullanımı \\
\hline Sülçevsi, İ., \& Sülçevsi, N. (2007). Türkçe 6. Priștine: Albas.
\end{tabular}

Tablo 2'de görüldüğü gibi, ünite şablonunda yer alan Dilimizi Öğrenelim bölümünde dil bilgisi konuları yer almaktadır. Tamamlayıcı Bilgiler bölümünde, Türkçenin dünya dilleri içerindeki yeri, edebiyat ve tür bilgisi, dil bilgisi konuları yer almaktadır. Bu bölümlerde yer alan içerikler günümüzde Türkiye'de dil bilgisi öğretimi konusundaki anlayışla uyuşmayacak şekilde, yalnızca açıklayıcı bilgilerle yetinmektedir. Etkinlik ya da alıştırmalarla öğrencinin bilgilerinin harekete geçirecek, dil bilgisini ve becerilerini kullanarak kalıcılığa katkı sağlayacak mahiyette bir içeriğe rastlamak mümkün değildir. Fakat bunun gelecek yıl başka öğrencilerin kullanması için yılsonunda ders kitaplarının idare teslim edilecek olması etkili olmuş olabilir. Kosova'da Türkçe ders kitaplarının basımı ve sayısal yeterliliği konusunda ciddi sorunlar olduğu görülmektedir.

Tablo 3. 6. Sınıf Türkçe Ders Kitabı Metinleri

\begin{tabular}{lll}
\hline \multicolumn{1}{c}{ Metnin Adı } & \multicolumn{1}{c}{ Yazarı/Yazarları } & \multicolumn{1}{c}{ Türü } \\
\hline Rüstem & Halide Edip ADIVAR & Öykü \\
Renkler Benim Sevdiklerim & Necati ZEKERİYA & Şiir \\
Kitaba Hürmet & Nurullah ATAÇ & Deneme \\
Bayram Saatçi & Süreyya YUSUF & Öykü \\
Eşeğin Suçu & La FONTAİNE & Fabl \\
Keloğlan İlim Peşinde & Türk masalı & Masal \\
Falaka & Ömer SEYFETTİN & Öykü \\
On Kasım & Cahit Sıtkı TARANCI & Şiir \\
Üç Dil & Bedri Rahmi EYÜBOĞLU & Şiir \\
Öğretmenler Günü & İsa SÜLÇEVSI & Mektup \\
Heidi'den & Johanna SPYRİ & Öykü \\
Evliya Çelebi Viyana'da & Evliya ÇELEBİ & Öykü \\
Türkü & Naim ŞABAN & Şiir \\
Uyku & Muzaffer İGÜ & Öykü \\
Dinlemek Üzerine & Haldun TANER & Deneme \\
Aydınlık için & Naim FRASHERİ & Şiir \\
Dağ Delen Delikanlı & Serpil URAL & Öykü \\
Kütüphanede Doğan Hikâye & Necati ZEKERİY & Öykü \\
İstiklal Marşı & Mehmet Akif ERSOY & Şiir \\
Karagöz ve Hacivat & Metin AND & Tiyatro \\
Eğri Minare & M. Necati SEPETÇİOĞLU & Efsane \\
Ana Gibi Yar Olur mu? & Nebahat SÜLÇEVSİ & Öykü \\
Kompozisyon & Mehmet KAPLAN & Deneme \\
Kompozisyon & Mehmet KAPLAN & Deneme \\
\hline
\end{tabular}




\begin{tabular}{lll}
\hline Papatya & Tevfik FIKRET & Şiir \\
Üç Elma & Eflatun Cem GÜNEY & Masal \\
Yeni Gemi & Namık KEMAL & Mektup \\
Dünya Çocuklarına & MïHNETI & Şiir \\
Alışkanlık & Michel De MONTAİGNE & Deneme \\
Nasrettin Hoca & Aziz NESİN & Biyografi \\
Memiş'in Tosunu & Reşit HANADAN & Öykü \\
İşitmek ve Dinlemek & Doğan CÜCELOĞLU & Deneme \\
Yolcu & Mehmet Emin YURDAKUL & Şiir \\
\hline
\end{tabular}

Sülçevsi, İ., \& Sülçevsi, N. (2007). Türkçe 6. Priştine: Albas.

Tablo 3'e göre, 6. Sınıf Türkçe Ders Kitabı'nda Türk ve dünya edebiyatından yazar ve şairlerin eserlerinden alınmış metinler bulunmaktadır. Ayrıca Kosovalı müelliflerin eserleri de bu metinler arasında yer bulmaktadır. Metinlerin hemen hemen her türden seçildiğini söylemek de mümkündür.

\section{Eğitimde Bilişsel Alan Basamaklarının Sınıflanması ve Yenilenmiş Bloom Taksonomisi}

Eğitim öğretim sürecinde öğrencilerin ulaşması hedeflenen davranış ya da kazanımların belirlenmesinde, amaçların aşamalı sınıflaması, yani taksonomi kavramının önemi, ortaya çıkmaktadır. Sönmez (2015), hedefler belirlenirken, basitten karmaşığa, kolaydan zora, somuttan soyuta olmak üzere birbirinin ön koşulu olacak şekilde aşamalı sıralamanın, önemli bir husus olduğuna dikkat çekmektedir. Dünyada bu anlamda kabul gören ve alan yazında bu anlamda ilk girişim olarak ortaya çıkan Bloom taksonomisi, ABD'de 1948'de birçok uzmanın katılımıyla fiilen başlayan, 1956 yılında bir yayınla noktalanan çalışmanın ürünüdür (Bloom, 1956; Tutkun ve Okay, 2012). Bu çalışmanın ortaya çıkışından bu yana geçen uzun sürede, eğitim bilimi açısından önemini halâ koruduğu görülen Bloom taksonomisinden; program geliştirme, eğitsel içerikler hazırlama, ölçme değerlendirme çalışmaları gibi birçok alanda yararlanılmıştır.

Tablo 4. Bloom Taksonomisi

\begin{tabular}{|c|c|}
\hline Bilgi & Analiz \\
\hline $\begin{array}{l}\text { Belirli bir alana özgü bilgiler } \\
\text { Belirli bir alanla ilgili bilgilerle ulaşma } \\
\text { araçları ve yolları bilgisi } \\
\text { Bir alandaki evrenseller ve soyutlamalarla } \\
\text { ilgili bilgi }\end{array}$ & $\begin{array}{l}\text { Ögelerin analizi } \\
\text { İlişkilerin analizi } \\
\text { Örgütleme ilişkilerinin analizi }\end{array}$ \\
\hline $\begin{array}{l}\text { Çevirme } \\
\text { Yorumlama } \\
\text { Yordama }\end{array}$ & $\begin{array}{l}\text { Sentez } \\
\text { Özgün bir iletişim muhtevası oluşturma } \\
\text { Bir plan veya işlemler takımı önerisi } \\
\text { oluşturma } \\
\text { Soyut ilişkiler takımı geliştirme }\end{array}$ \\
\hline Uygulama & $\begin{array}{l}\text { Değerlendirme } \\
\text { İç kanıtlar bakımından yargılama } \\
\text { D1ş kanıtlar bakımından yargılama }\end{array}$ \\
\hline $\begin{array}{l}\text { Anderson, L. W., \& Krathwohl, D. R. (Ed.). } \\
\text { assessing: A revision of Bloom's taxonomy o } \\
\text { Anderson, L. W., \& Krathwohl, D. R. (2010). } \\
\text { sinıflama (Kısaltılmıs Basım). (D. A. Özcelik, Ce }\end{array}$ & $\begin{array}{l}\text { 01). A taxonomy for learning, teaching and } \\
\text { educational objectives. New York: Longman. } \\
\text { rrenme öğretim ve değerlendirme ili ilgili bir } \\
\text { Ankara: Pegem Akademi. }\end{array}$ \\
\hline
\end{tabular}

Eğitsel hedeflerin tabloda hangi hücreye karşılık geldiği belirlemek adına iki boyutlu bir değerlendirme yapmak gerekmektedir. Bilgi boyutuna bakıldığında olgusal bilgi, kavramsal bilgi, 
işlemsel bilgi, biliş ötesi bilgi türleri görülmektedir. Olgusal bilgi belli konu, motif veya temalara denk gelmektedir. Yani terminoloji bilgisi, ögeler bilgisi içerir. Ögeler arasındaki ilişkilerin bilgisine geçildiğinde, kavramsal bilgi ortaya çıkmaktadır. Bu tür bilgiler daha karmaşık ve örgütlü bilgilerdir. Kategoriler, yapılar, sınıflamalar şeklinde kendini gösterir. İşlemsel bilgi ise bir şeyin nasıl yapılacağının bilgisidir. Üst bilişsel bilgi, bilişle ilgilidir ve bireyin bilişsel görevine yönelik bilgisini ifade eder. Başka ifade ile bireyin kendi öğrenmeleri, bilgileri hakkındaki bilgisini içerir (Anderson ve Krathwohl, 2001, 2010). Bilişsel işlem basamaklarında bulunan hatırlama, anlama, uygulama, değerlendirme ve yaratma öğrencinin bilgiyi kullanma biçimi ile ilgilidir. Hatırlama basamağı en alt seviyededir. Burada bilginin ezberden çıkarılması ya da hazır halde verilen bilginin işe koşulması söz konusudur. Örneğin, olaya dayalı bir metinle ilgili uygulanan 5N1K tekniği, öğrencinin hatırlama düzeyinden işlemler yapmasını gerektirecektir. Anlama basamağında, yorumlama, örneklendirme, özetleme, sonuç çıkarma gibi işlemler yapılması gerekir. Aynı olaya dayalı metinde geçen olayları olduğu gibi aktarılmasından ziyade öğrencinin kendi bakış açısına göre ifade etmesi, özetlemesi ve kendince sonuçlar çıkarması bu basamakta değerlendirilebilir. Uygulama basamağında, birey elindeki bilgileri, işleme tabii tutar ve bundan sonuçlar elde eder. Türkçe dersi özelinde düşünülürse, özellikle dil bilgisi ile ilgili kazanımlarda uygulama basamağının öne çıkması işlevsel olabilmektedir: Dil bilgisel ögeleri belirlemek, dil bilgisel ilişkileri belli prosedürleri uygulayarak ortaya çıkarmak gibi. Analiz basamağı ve bunu takip eden değerlendirme ve yaratma basamakları, üst düzey bilişsel işlemler olarak değerlendirilmektedir. Analiz basamağında birey, konuyu veya materyali bileşenlerine ayırır ve bu bileşenler arasındaki ilişkileri belirler. Bu ilişkiler temelinde bileşenler arasında bir örgütlemeye gider. Bu şekilde bir sınıflandırma da ortaya koymuş olur. Türkçe derslerinde özellikle yazı kompozisyonları oluştururken analiz ve değerlendirme basamaklarına denk gelen işlemlerin yapılması gerekmektedir. Değerlendirme basamağında birey ele aldığı konu ya da materyalle ilgili belli standartlara, kriterlere dayanarak çıkarımlarda bulunur. En üst aşamada, yeni bir ürün ortaya koymak ile ilişkili olarak yaratma basamağı bulunmaktadır. Burada özgünlük öne çıkmaktadır. Yine Türkçe dersi açısından bakıldığında, öğrencinin belirlenen kazanımlara, kendine özgü yollardan ulaşması ya da belirli yollarla kendine özgü ürünler ortaya koyması akla gelebilir. Örneğin, konuşma kurallarını uygulama kazanımıyla ilişkili etkinliklerde öğrencinin ses tonu ve vurgu açısından özgün bir tarz oluşturması ya da okuduğunu anlama kazanımı ile ilgili olarak metni yorumlama anlamında ortaya koyduğu özgün bir yaklaşım bu bağlamda değerlendirilebilir.

\section{Yöntem}

Bu bölümde araştırma modeli, inceleme nesnesi, verilerin toplanması ve verilerin analizi hakkında bilgiler bulunmaktadır. 


\section{Araştırmanın Modeli}

Çalışma, nitel araştırma türündedir. Nitel araştırma, gözlem, görüşme ve doküman analizi gibi nitel bilgi toplama yöntemlerinin kullanıldığı, algıların ve olayların doğal ortamda gerçekçi ve bütüncül bir biçimde ortaya konulmasına yönelik nitel bir sürecin izlendiği araştırmalar olarak tanımlanabilir (Yıldırım ve Şimşek, 2016, s. 41). Nitel araştırma yöntemlerinde sık kullanılan modellerden durum çalışması deseni bu çalışmada tercih edilmiştir. Bu tür çalışmalarda, incelenen durum; birey, kurum, ortam, süreç vb. olabilmektedir (Yıldırım ve Şimşek, 2016, s. 73).

$\mathrm{Bu}$ çalışma bağlamında durum, ders materyali olarak kullanılan bir kitabın işlevselliği ve amaca hizmet etme durumudur. Durum çalışmalarında incelenen durumun bütüncül bir yaklaşımla derinlemesine incelenmesi söz konusudur. Hangi etkenlerin ne derece bu durumu etkilediğine odaklanmak gerekmektedir (Yıldırım ve Şimşek, 2016, s. 73-74). Bu çalışmada da ders kitabı ile ilgili kazanımların ilişkisi ve tasarlanan alıştırma/etkinliklerin bu kazanımları gerçekleştirebilme kapasitesinin derinlemesine incelenmesi amaçlanmakta, bunlarla ilişkili muhtemel etkenler açığa çıkarılmaya çalışılmaktadır.

\section{Verilerin Toplanması ve Analizi}

Verilerin toplanmasında, doküman analizi yöntemi kullanılmıştır. Ders kitabının öğretim programı kazanımlarını yansıtma durumunu anlamak adına, ders kitabı ve öğretim programı içeriği analiz edilmiştir. Metin altı sorularının Yenilenmiş Bloom Taksonomisine göre değerlendirilmesinin sebebi program geliştirme sürecinde bu taksonominin temel alınmasıdır.

Veri analizinin ilk aşamasında, öğretim programında (Kosova Eğitim Bilim ve Teknoloji Bakanlığı, 2003) geçen kazanımların ders kitabında bulunma durumu belirlenmiştir. Buna göre 6. sınıf Türkçe Ders Kitabı'nda hedef/kazanımın bulunması durumu " $\checkmark$ " işareti ile bulunmaması durumu da " $X$ " işareti ile gösterilmiştir. Veri analizinin son aşamasında, ders kitabının metin altı sorularının bilişsel alan basamakları açısından değerlendirilmesinde, Yenilenen Bloom Taksonomisinde çerçevesi belirlenen bir yaklaşım esas alınmıştır (Anderson ve Krathwohl, 2001).

Metin altı sorularının Yenilenmiş Bloom Taksonomisine göre konumu tabloya yerleştirilirken alıştırma, soru ya da etkinliğin, bilişsel işlem basamakları ve bilgi türleri açısından durumunu doğru anlamak gerekmektedir. Bunun için ilgili alanyazın araştırmacılar tarafından taranmıştır (Anderson ve Krathwohl, 2001, 2010; Aslan ve Atik, 2018; Bloom, 1956; Bümen, 2010; Forehand, 2005; Köğce, Aydın ve Yıldız, 2009; Krathwohl, 2002; Oran ve Karalı, 2019; Sallabaş ve Yılmaz, 2020; Tutkun ve Okay, 2012; Ulum ve Taşkaya, 2019; Yüksel, 2007).

Bilişsel alan sınıflaması tablosu yerleşimi ve kodlama örnekleri aşağıda görülmektedir. 
Tablo 5. Yenilenmiş Bloom Taksonomisi

\begin{tabular}{llccc}
\hline & & \multicolumn{3}{c}{ Bilgi Birikimi Boyutları } \\
\hline & & $\begin{array}{c}\text { A. Olgusal } \\
\text { bilgi }\end{array}$ & $\begin{array}{l}\text { B. Kavramsal } \\
\text { bilgi }\end{array}$ & $\begin{array}{c}\text { D. Üst bilişsel } \\
\text { bilgi }\end{array}$ \\
\hline Bilişsel İşlem & 1. Hatırlama & A.1 & B.1 & D.1 \\
Basamakları & 2. Anlama & A.2 & B.2 & D.2 \\
& 3.Uygulama & A.3 & B.3 & D.3 \\
& 4. Çözümleme & A.4 & B.4 & D.4 \\
& 5. Değerlendirme & A.5 & B.5 & D.5 \\
& 6. Yaratma & A.6 & B.6 & D.6 \\
\hline
\end{tabular}

Anderson, L. W., \& Krathwohl, D. R. (Ed.). (2001). A taxonomy for learning, teaching and assessing: A revision of Bloom's taxonomy of educational objectives. New York: Longman. Anderson, L. W., \& Krathwohl, D. R. (2010). Öğrenme öğretim ve değerlendirme ili ilgili bir sınıflama (Kısaltılmış Basım). (D. A. Özçelik, Çev.) Ankara: Pegem Akademi.

A.1. Hücresi örneği: Mahluk, muharebe, iğreti, poyraz sözcüklerinin anlamların sözlükten bulup yazını.

A.2. Hücresi örneği: Siz de yaş-, oku-, it-, eylem kök ve gövdelerine -yor ekini ekleyerek şimdiki zaman kipinde kişilere göre çekimleyiniz.

A.3. Hücresi örneği: Yukarıda verilen tariflere göre okuduğunuz hikâyenin dü̆̆̈̈m ve çözüm kısımlarını bulmaya çalışınız.

A.4. Hücresi örneği: Bayram Saatçi'nin dükkanını kapatıp, göç etme nedenini tartışınız.

A.5. Hücresi örneği: "Bir lisan bir insan." atasözünü açıklayan bir kompozisyon yazını.

A.6. Hücresi örneği: Bu özellikle herhangi bir metin altı soru tespit edilmemiştir.

B.1. Hücresi örneği: Bellemek, iş tutmak, temasla dokunmak, sözcük ve sözcük gruplarmın metin içerisindeki anlamlarını çözmeye çalışını.

B.2. Hücresi örneği: Yukarıda okuduğunuz metinde yazar, okumanın öneminden bahsediyor. Yazar okumanın öneminden bahsederken kendi düşüncelerini mi aktarıyor, yoksa bilimsel verilere mi dayanyor?

B.3. Hücresi örneği: Okuduğunuz şiirin mısraları arasında uyak olup olmadığını ve şïrde hece ölçüsü olup olmadığını belirleyiniz.

B.4. Hücresi örneği: Çok çalışarak zengin olmuş birilerini tanıyor musunuz? Çok çalışıp, dürüst kazanmanın yararlarımı sınıfta tartışınız.

B.5. Hücresi örneği: Hayatta en hakiki mürşit ilimdir." sözünden hareket ederek, bir kompozisyon yazını.

B.6. Hücresi örneği: Bu özellikle herhangi bir metin altı soru tespit edilmemiştir.

D.1. Hücresi örneği: Kana kana bakmak, dört nala koşmak, dolu dizgin uçmak ifadelerinden ne anlyorsunuz? 
D.2. Hücresi örneği: Hangi renkleri en çok seversiniz neden?

D.3. Hücresi örneği: Bu özellikle herhangi bir metin altı soru tespit edilmemiştir.

D.4. Hücresi örneği: Siz hangi amaçla neden okursunuz?

D.5. Hücresi örneği: Sevdiğiniz şeylerin olumlu yönlerini nasıl gözler önüne serersiniz? Bu konu ile ilgili bir kompozisyon yazını.

D.6. Hücresi örneği: Bu özellikle herhangi bir metin altı soru tespit edilmemiştir.

Yapılan kodlamaların güvenirliğini belirlemek adına, Miles ve Huberman (1994) güvenirlik formülü kullanılmıştır. Bu formülde kodlayıcılar arasındaki uyumu hesaplamak mümkün olmaktadır. Araştırmacıların yaptıkları kodlamalardan birbiriyle uyuşmayanlar tekrar gözden geçirilmiş ve görüş birliğine varılmıştır. Kodlama işlemi için güvenilirlik değeri, 0,94 olarak belirlenmiştir.

\section{Bulgular}

\section{Sınıf Türkçe Ders Kitabı'nın Kosova Alt Ortaöğretim 6. Sınıf Türkçe Öğretim Plan ve Programı}

\section{Kazanımları Açısından Durumu}

Programda ifade edildiği şekliyle "hedefler" dinleme/izleme, okuma, konuşma, yazma ve dil bilgisi öğrenme alanlarına denk gelmektedir (Kosova Eğitim Bilim ve Teknoloji Bakanlığı, 2003).

Tablo 6. 6. Sınıf Türkçe Ders Kitabı Kazanımları

\begin{tabular}{|c|c|c|}
\hline Öğrenme Alanı & Kitapta Bulunv & na Durumu \\
\hline \multirow{3}{*}{$\begin{array}{l}\text { Dinleme } \\
\text { İleme }\end{array}$} & Karşısındakinin sözünü kesmeden dinleyebilme & $\mathrm{X}$ \\
\hline & $\begin{array}{l}\text { Kelime hazinesini, genel kültürünü ve iç dünyasını zenginleştirip } \\
\text { çeşitlendirecek yayın, film ve konferansları izleyebilme }\end{array}$ & $x$ \\
\hline & Dinlediklerinin ve izlediklerinin ana fikrini kavrayabilme & $\checkmark$ \\
\hline \multirow[t]{7}{*}{ Okuma } & $\begin{array}{l}\text { Sesli ve sessiz okuma hızını arttırma ve tekniğini kusursuz duruma } \\
\text { getirme }\end{array}$ & $\mathrm{X}$ \\
\hline & $\begin{array}{l}\text { Kitap sevgisini geliştirerek boş zamanlarını okuyarak değerlendirme } \\
\text { alışkanlığı edinme }\end{array}$ & $\checkmark$ \\
\hline & $\begin{array}{l}\text { Dizin, dipnot, sözlük, ansiklopedi ve diğer başvuru kaynaklarından } \\
\text { yararlanma becerisini geliştirmek }\end{array}$ & $\checkmark$ \\
\hline & Okuduklarını muhteva açısından anlayabilme & $\checkmark$ \\
\hline & $\begin{array}{l}\text { Seçilen bir parçayı tonlamayı ve vurguyu uygulayarak ve canlandırma } \\
\text { ile okuyabilme }\end{array}$ & $\checkmark$ \\
\hline & Düzyazı veya şiirin oluşturulma planını çıkarabilme & $\checkmark$ \\
\hline & Okuduklarının şekil ve içerik özelliklerini kavrayabilme & $\checkmark$ \\
\hline \multirow[t]{3}{*}{ Yazma } & $\begin{array}{l}\text { Yazım ve söz dizimi yanlışı yapmadan yazabilme, noktalama } \\
\text { işaretlerini yerinde kullanabilme }\end{array}$ & $\checkmark$ \\
\hline & $\begin{array}{l}\text { Düşünce, arzu ve isteklerini düzgün, belli bir süre içinde ve planlı bir } \\
\text { şekilde yazıya aktarabilme }\end{array}$ & $\checkmark$ \\
\hline & Resmi yazışmaları öğrenme & $\mathrm{X}$ \\
\hline \multirow[t]{2}{*}{ Konuşma } & $\begin{array}{l}\text { Günlük yaşantılarını selamlaşmaları ve özür ifadelerini her ortamda } \\
\text { görgü kurallarına uygun bir şekilde dile getirebilme }\end{array}$ & $\mathrm{X}$ \\
\hline & $\begin{array}{l}\text { Düşünce, arzu ve isteklerini düzgün, belli bir süre içinde ve planlı bir } \\
\text { şekilde anlatabilme }\end{array}$ & $\mathrm{X}$ \\
\hline \multirow[t]{2}{*}{ Dil Bilgisi } & Anlamlarına göre cümle ve kelimeleri doğru vurgulayabilme & $\checkmark$ \\
\hline & Kelimelerin değişik anlamlarını kavrayabilme & $\checkmark$ \\
\hline
\end{tabular}




\begin{tabular}{ll}
\hline Sesteş, anlamdaş, zıt anlamlı kelimeleri kullanabilme & $X$ \\
\hline Ünlü uyumlarını kavrayıp uygulayabilme & $X$ \\
\hline $\begin{array}{l}\text { Kelime türlerini cümle içindeki anlam ve görevlerine göre tanıma ve } \\
\text { kullanabilme }\end{array}$ & $\checkmark$ \\
\hline Kelime yapısı ve türetme yollarını kavrayabilme & $\checkmark$ \\
\hline Kelime ve ekleri anlayıp doğru yazabilme & $\checkmark$ \\
\hline Noktalama işaretlerini doğru kullanabilme & $\checkmark$ \\
\hline $\begin{array}{l}\text { Eylem (fiil) kiplerini, birleşik zamanlarını, çatılarını, ek eylem, yardımcı } \\
\text { eylem, birleşik eylem, eylemsileri kavrama ve doğru kullanabilme }\end{array}$ & $\checkmark$ \\
\hline $\begin{array}{l}\text { Cümle ögelerinin siralanışını, sıralanışa göre anlam değişikliğinini } \\
\text { kavrayıp cümleyi buna göre kurma }\end{array}$ & $\checkmark$ \\
\hline Cümle türlerini öğrenebilme & $\checkmark$ \\
\hline
\end{tabular}

Öğretim programında yer alan hedef/kazanımların çă̆daş dil eğitimi anlayışlarının aksine dil bilgisi ağırlıklı olduğu görülmektedir. 6. sınıf Türkçe Ders Kitabı'nda da buna benzer şekilde dil bilgisi konularının yoğun bir şekilde yer bulduğunu fakat temel dil becerilerini kazandırmaya yönelik etkinlik ya da bilgilerin de son derece kısıtlı olduğu görülmektedir. Dil bilgisi konularının öğrencilere paket bilgiler şeklinde, hazır sunulması da dil eğitimi açısından geleneksel bir yaklaşım olarak değerlendirilebilir.

Tablo 6'ya göre; "Karşısındakinin sözünü kesmeden dinleyebilme," "Kelime hazinesini, genel kültürünü ve iç dünyasını zenginleştirip çeşitlendirecek yayın, film ve konferansları izleyebilme," "Sesli ve sessiz okuma hızını artırma ve tekniğini kusursuz duruma getirme," "Resmi yazışmaları öğrenme," "Günlük yaşantılarını selamlaşmaları ve özür ifadelerini her ortamda görgü kurallarına uygun bir şekilde dile getirebilme," "Düşünce, arzu ve isteklerini düzgün, belli bir süre içinde ve planlı bir şekilde anlatabilme," “Sesteş, anlamdaş, zıt anlamlı kelimeleri kullanabilme,” “Ünlü uyumlarını kavrayıp uygulayabilme," kazanımlarının 6. sınıf Türkçe Ders Kitabı'nda karşılığı yoktur. "Dinlediklerinin ve izlediklerinin ana fikrini kavrayabilme," "Kitap sevgisini geliştirerek boş zamanlarını okuyarak değerlendirme alışkanlığı edinme," "Dizin, dipnot, sözlük, ansiklopedi ve diğer başvuru kaynaklarından yararlanma becerisini geliştirmek," “Okuduklarını muhteva açısından anlayabilme," "Seçilen bir parçayı tonlamayı ve vurguyu uygulayarak ve canlandırma ile okuyabilme," “Düzyazı veya şiirin oluşturulma planını çıkarabilme," “Okuduklarının şekil ve içerik özelliklerini kavrayabilme," "Yazım ve söz dizimi yanlışı yapmadan yazabilme, noktalama işaretlerini yerinde kullanabilme," "Düşünce, arzu ve isteklerini düzgün, belli bir süre içinde ve planlı bir şekilde yazıya aktarabilme," "Anlamlarına göre cümle ve kelimeleri doğru vurgulayabilme," "Kelimelerin değişik anlamlarını kavrayabilme," "Kelime türlerini cümle içindeki anlam ve görevlerine göre tanıma ve kullanabilme," “Kelime yapısı ve türetme yollarını kavrayabilme," “Kelime ve ekleri anlayıp doğru yazabilme," “Noktalama işaretlerini doğru kullanabilme," “Eylem (fiil) kiplerini, birleşik zamanlarını, çatılarını, ek eylem, yardımcı eylem, birleşik eylem, eylemsileri kavrama ve doğru kullanabilme," “Cümle ögelerinin sıralanışını, sıralanışa göre anlam değişikliğini kavrayıp cümleyi buna göre 
kurma," "Cümle türlerini öğrenebilme," kazanımlarını gerçekleştirmeye yönelik unsurlar 6. sınıf Türkçe Ders Kitabı'nda bulunmaktadır.

$\mathrm{Bu}$ bulgulara göre ders kitabı dinleme/ izleme ve konuşma alanı ile ilgili kazanımları gerçekleştirmek bakımından yetersiz kalmaktadır. Okuma, yazma ve dil bilgisi alanı kazanımlarının ise görece yeterli düzeyde kitapta yer aldığı görülmektedir.

\section{6. sınıf Türkçe Ders Kitabı Metin Altı Sorularının Yenilenmiş Bloom Taksonomisine Göre Durumu}

Tablo 7'de 6. sınıf Türkçe Ders Kitabı, metin altı sorularının Yenilenmiş Bloom Taksonomisine göre durumu görülmektedir.

Tablo 7. Metin Altı Sorularının Yenilenmiş Bloom Taksonomisine Göre Durumu

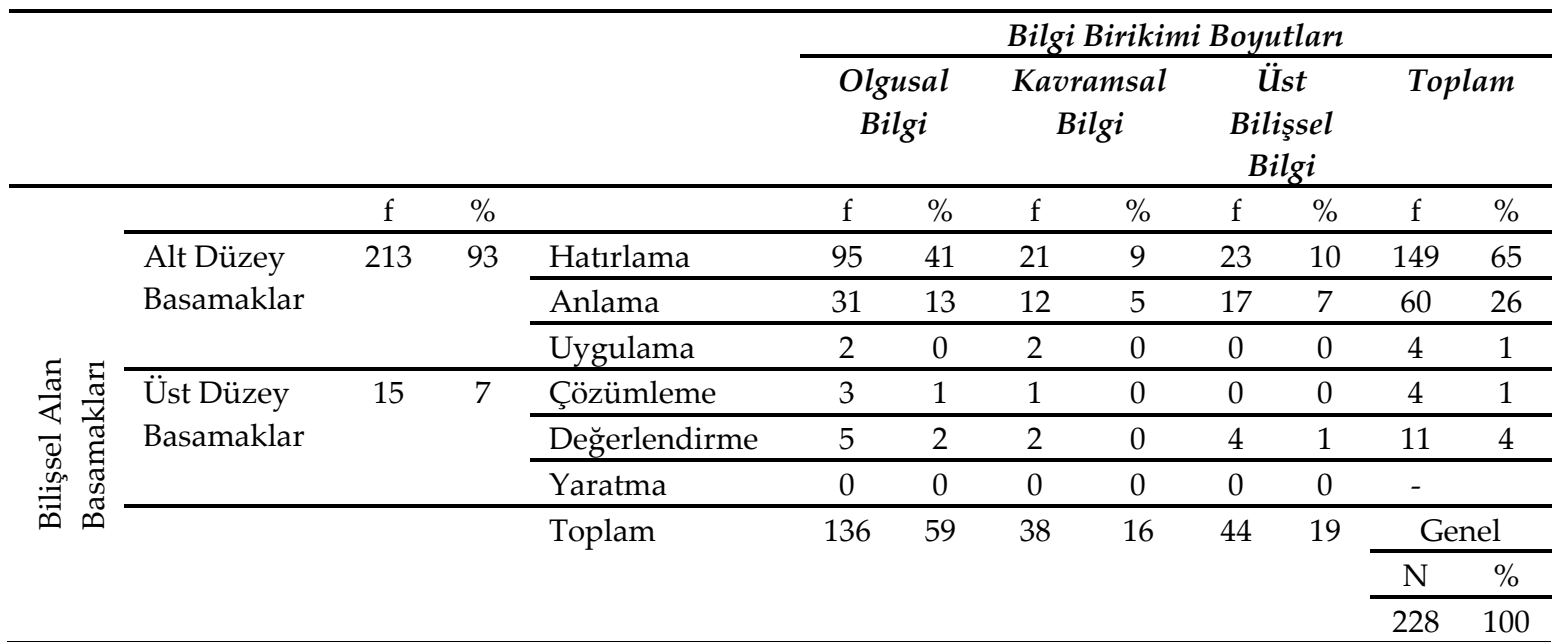

Anderson, L. W., \& Krathwohl, D. R. (Ed.). (2001). A taxonomy for learning, teaching and assessing: A revision of Bloom's taxonomy of educational objectives. New York: Longman. Anderson, L. W., \& Krathwohl, D. R. (2010). Öğrenme öğretim ve değerlendirme ili ilgili bir sımıflama (Kısaltılmış Basım). (D. A. Özçelik, Çev.) Ankara: Pegem Akademi.

Tablo 7'ye göre, 6. sınıf Türkçe Kitabı metin altı sorularının \%93'ü bilişsel alanın alt düzey basamaklara denk gelmektedir. 6. sınıf Türkçe Kitabı metin altı sorularında \%7 oranında üst düzey basamaklara denk gelen ögeler bulunmuştur. Bu da açıkça göstermektedir. 6. sinıf Türkçe Kitabı metin altı soruları üst düzey bilişsel becerilerin kazandırılması anlamında son derece yetersizdir.

6. sınıf Türkçe Kitabı metin altı sorularının $\% 65$ 'i hatırlama basamağındadır. $\% 26$ oranında ögenin de anlama basamağında olduğu görülmektedir. Uygulama ve değerlendirme basamakları ise \%1 oranındadır. Değerlendirme basamağında \%4 öge tespit edilirken, yaratma basamağında hiçbir öge tespit edilmemiştir. Özellikle yaratma basamağında hiçbir öge bulunmaması dikkat çekicidir. Aynı şekilde değerlendirme ve çözümleme basamaklarında ögelerin de yetersiz olduğu görülmektedir.

Bilgi türleri açısından dağılıma bakıldığında, metin altı sorularında \%59 oranında olgusal bilgiler, \%16 oranında kavramsal bilgiler, \%19 oranında üst bilişsel bilgiler olarak değerlendirilebilecek bilgilerin kullanıldığı görülmektedir. Olgusal bilgilerde yaşanan yığılma hemen göze çarpmaktadır. Bu tür bilgilerin daha katı, yoruma kapalı olduğu söylenebilir. Başka bir deyişle, çoğunlukla ezber yoluyla elde edilen bu bilgilerin, yaygınlaşması da daha çok nakil yoluyla olmaktadır. Ders kitabın hemen 
hemen her metinin altında birkaç tane sözlükten, sözcük tanımı öğrenilmesi/ezberlenmesine dair yönerge, bu oranın artmasına etki etmiştir. Başka bir dikkat çekici nokta da işlemsel bilgiye hiç yer verilmemesidir. Metin altı soruları ya da alıştırmalarının işlevselliği açısından bunun bir sorun teşkil ettiği, dengesiz dağılımın daha da arttığı ifade edilebilir.

\section{Tartışma}

Türkçe Ders Kitabı'nda bulunan metin altı sorularının Yenilenmiş Bloom Taksonomisi açısından değerlendirildiği iki çalışmadan biri 2013, diğeri 2020 yılında yapılmıştır (Kuzu, 2013; Sallabaş ve Yılmaz, 2020). Sallabaş ve Yılmaz'ın (2020) ulaştığı sonuçlara göre, metin altı sorularının \%32'si hatırlama basamağına, \%35'i anlama basamağına, \%11'i çözümleme basamağına, \%14'ü değerlendirme basamağına, \%4'ü yaratma basamağına denk gelmektedir. Kuzu (2013) tarafından yapılan çalışmada ise 6. Sınıf Türkçe Ders Kitabı'ndaki metin altı soruların; \%36'sı hatırlama, \%39'u anlama düzeyine, \%25'i de kalan düzeylere denk gelmektedir. Bu çalışmada yalnızca hatırlama ve anlama düzeyinin incelenmesi bakımından bir sınırlılık olsa da iki çalışmada da dağılım, hemen hemen aynıdır. Bu çalışmada ulaşılan sonuçlarla karşılaştırıldığında Kosova'da 6. sınıflarda kullanılan ders kitabında Türkiye'deki Türkçe ders kitaplarına kıyasla, hatırlama düzeyinde bir yığılma olduğu görülmektedir. Hatırlama düzeyi, en alt basamak olarak değerlendirildiğine göre, Kosova'da kullanılan 6. sınıf Türkçe Ders Kitabı'nın açıkça alt düzey becerilere odaklandığı, bunun da dengesiz bir dağılım yarattığı söylenebilir. Anlama basamağı oranlarında kitaplar birbirine benzemekte, üst düzey basamaklar olan çözümleme, değerlendirme ve yaratma basamaklarında Kosova'da kullanılan ders kitabı yetersiz kalmaktadır. Aslan ve Atik (2018) tarafında yapılan bir çalışmada 2015 ve 2018 yılı İlköğretim Türkçe Dersi Öğretim Programı kazanımları, bu çalışmaya benzer şekilde Yenilenmiş Bloom Taksonomisine göre incelenmiştir. Buna göre, 2015 yılı kazanımları uygulama, anlama ve çözümleme basamaklarına uygunken, 2017 programında ise kazanımların büyük çoğunluğunun alt düzeylerle ilgili olduğu sonuçlarına ulaşılmıştır.

İlkokul 2, 3 ve 4. sınıf Türkçe ders ve çalışma kitaplarında yer alan etkinlikleri, Yenilenmiş Bloom Taksonomisine göre incelendiği bir araştırmadan elde edilen sonuçlara göre, Yenilenmiş Bloom Taksonomisinin bilişsel beceri boyutunu oluşturan tüm basamaklar, çeşitli oranlarda dağılım göstermektedir. Bilgi boyutunu ögeler yoğunluğa göre sırasıyla; olgusal bilgi, kavramsal bilgi, işlemsel bilgi, üst bilişsel bilgidir (Ulum ve Taşkaya, 2019). Bu çalışmada olduğu gibi olgusal bilgilerde bir yoğunlaşma görülmektedir. Bu kitaplarda olduğu gibi genel olarak ders kitaplarında yer verilen etkinlikler ya da metin altı sorularının bilgi türleri açısından dengeli bir dağılım göstermesi gerektiği, bu noktada ifade edilmelidir. 


\section{Sonuç}

6. sınıf Türkçe Ders Kitabı metin altı soruları ve hazırlık çalışmaları, öğretim programında belirtilen 26 kazanımdan 18 tanesini içermekte buna karşın 8 tanesine ilişkin herhangi bir içerik bulunmamaktadır. Bu durum kitabın ihtiyaçları cevap verebilmesi adına soru işaretleri yaratmaktadır. Kosova' da ortaokul seviyesinde basılmış iki adet kitap bulunmaktadır. Bunlar 6. ve 7. sınıf Türkçe ders kitaplarıdır. Öbür taraftan da 8. ve 9. sınıf kitaplarının basılmadığı görülmektedir (Eryılmaz ve Demir, 2020). Dolayısıyla eldeki kitapların kazanımların tamamını içermemesi, verimli bir Türkçe eğitimi yürütülmesi açısından olumsuz sonuçlar doğuracaktır.

6. sınıf Türkçe Kitabı metin altı sorularının \%93'ü bilişsel alanın alt düzey basamaklarına, \%7'si üst düzey basamaklara denk gelmektedir. Bu sonuçlara bakıldığında, metin altı soruların üst düzeyde bilişsel beceriler kazandırılması açısından yetersiz olduğu görülmektedir.

6. sınıf Türkçe Kitabı metin altı sorularının bilişsel süreçler boyutunda; \%65'i hatırlama, \%26'sının anlama \%1'inin uygulama, \%4'ünün değerlendirme basamağında olduğu sonucuna ulaşılmıştır. Yaratma basamağında öge tespit edilmemiştir. Bu dengesiz dağılım ve üst düzey becerilerdeki eksiklik ders kitabının bu anlamda işlevini yerine getirmediğini göstermektedir. 6. sınıf Türkçe Kitabı metin altı sorularının, bilgi türleri açısından dağılımına bakıldığında, \%59 oranında olgusal bilgiler, \%16 oranında kavramsal bilgiler, \%19 oranında üst bilişsel bilgiler olarak değerlendirilebilecek bilgilerin kullanıldığı görülmektedir. Burada da dengesiz bir dağılım söz konusudur. Olgusal bilgilerin yoğunluğu göze çarpmaktadır. Bunun yanında işlemsel bilgi türünde hiçbir öge tespit edilmemiştir.

Çalışma sonuçları, eldeki verilere göre birçok sorunu ortaya koymaktadır. Fakat Kosova gibi bir ülkede Türkçe ders kitabı hazırlanması, basılması ile ilgili sorunları göz ardı etmek de mümkün değildir. Örneğin incelenen ders kitabında yazma etkinlikleri hemen hemen yoktur. 6. sınıf Türkçe ders kitabının ilk basımından 2020 yılına değin geçen 13 yılda, 2007 ve 2013 yıllarında, iki defa sınırlı sayıda olmak üzere basılmıştır. 6. sınıf kademesine geçen öğrenciler bu kitabı 1 yıl kullandıktan sonra, bir alt sınıfa devretmektedir. Bu durumda yıllarca el değiştirecek bir kitapta yazma etkinlikleri tasarlamak, kitap yazarı açısından da düşündürücü olmalıdır.

Ulaşılan sonuçlar temelinde Kosova'da Türkçe ders kitabı hazırlama sürecine dâhil olacak uzmanlar için bazı öneriler öne sürülebilir:

1. 6. sınıf Türkçe Ders Kitabı ve tasarlanacak/basılacak diğer ders kitaplarının mevcut Türkçe öğretim programının kazanımlarını tam olarak yansıtması gerekmektedir. 
2. 6. sınıf Türkçe Ders Kitabı ve tasarlanacak/basılacak diğer ders kitaplarının, metin altı sorularının bilişsel alan basamaklarını dengeli bir şekilde yansıtması gerektiği göz önünde bulundurulmalıdır.

3. 6. sınıf Türkçe Ders Kitabı ve tasarlanacak/basılacak diğer ders kitaplarının, metin altı soruları çağın anlayışına uygun şekilde öğrenciyi daha katılımcı, araştırmacı olmaya yönelten tarzda olmalıdır. 6. sınıf Türkçe Ders Kitabı'nda metinlerden sonra 5N1K tekniğine göre sorular oluşturulmuştur. Farklı tarzlarda, öğrencilerin ilgilerini çekecek etkinlikler tasarlanması; görseller kullanılması, güncel gelişmelerle ilintiler kurulması bu noktada ihmal edilmiş fakat önemli hususlardır.

\section{Kaynaklar}

Anderson, L. W., \& Krathwohl, D. R. (Ed.). (2001). A taxonomy for learning, teaching and assessing: A revision of Bloom's taxonomy of educational objectives. New York: Longman.

Anderson, L. W., \& Krathwohl, D. R. (2010). Öğrenme öğretim ve değerlendirme ili ilgili bir sinıflama (Kısaltılmış Basım). (D. A. Özçelik, Çev.) Ankara: Pegem Akademi.

Aslan, M., \& Atik, U. (2018). 2015 ve 2017 ilkokul Türkçe dersi öğretim programı kazanımlarının revize edilmiş Bloom taksonomisine göre incelenmesi Uluslararası Türkçe Edebiyat Kültür Ĕ̆itim (TEKE) Dergisi, 7(1), 528-547.

Bloom, B. S. (Ed.) (1956). Taxonomy of educational objectives. Vol. 1: Cognitive domain. New York: McKay.

Bümen, N. T. (2010). Program geliştirmede bir dönüm noktası: Yenilenmiş Bloom taksonomisi. Eğitim ve Bilim, 32(142), 3-14.

Demir, N. (2014). Dil, tarih, kültür ve edebiyat araştırmaları. Ankara: Edge Akademi.

Duman, A. (2003). Türk soylulara Türkiye Türkçesi öğretiminde metin seçimi. Türklük Bilimi Araştırmaları, 13(1), 151-156.

Eryılmaz, R. (2020). Kosova'da Türkçe öğretimi. (Doktora tezi). https://tez.yok.gov.tr sayfasından erişilmiştir.

Eryılmaz, R., \& Demir, N. (2020). Kosova'da yaşayan Türklerin ana dilde eğitiminde kullanılan 7. sınıf Türkçe ders kitabının biçim, içerik ve öğretim programına uygunluk açısından değerlendirilmesi. Uluslararası Ders Kitapları ve Eğitim Materyalleri Dergisi, 3(2), 353-370. https://dergipark.org.tr/en/pub/ijotem/issue/57627/755958 sayfasından erişilmiştir.

Forehand, M. (2005). Bloom's taxonomy: Original and revised. http://projects.coe.uga.edu/epltt/ sayfasından erişilmiştir.

Kayadibi, N. (2017). Makedonya'da ilköğretim okullarında Türkçe eğitimi 7. sınıf örneği. (Doktora tezi). https://tez.yok.gov.tr sayfasından erişilmiştir. 
Kelağa, A. İ. (2005). Yunanistan'da (Batı Trakya'da) iki dilli eğitim veren azınlık okullarında Türkçe ve Yunanca eğitim gören öğrencilerin okudŭ̆unu anlama ve yazılı anlatım becerilerinin değerlendirilmesi. (Doktora tezi). https://tez.yok.gov.tr sayfasından erişilmiştir.

Koro, B. (2013). 21. yüzyılın başlangıcında Kosova eğitim sistemi ve Türkçe eğitimi. Balkan Türkoloji Araştırmaları Merkezi (BAL-TAM), 12(3), 355-369.

Kosova Eğitim Bilim ve Teknoloji Bakanlığı (2003). Alt Seviye Ortaöğretim Altıncı Sını Öğretim Plan ve Programi. Priştine.

Kosovo Agency of Statistics (2018). Education statistics in Kosovo. Priştine.

Köğce, D., Aydın, M., \& Yıldız, C. (2009). Bloom taksonomisinin revizyonu: Genel bir bakış. İlköğretim Online, 8(3), 1-7.

Krathwohl, D. R. (2002). A revision of Bloom's taxonomy: An overview. Theory into Practice, 41(4), 212218.

Kurt, B. (2017). Gagauzya bölgesinde Türkiye Türkçesi öğretimi. Ankara: Son Çağ.

Kuzu, T. S. (2013). Türkçe ders kitaplarındaki metin altı sorularının yenilenmiş Bloom taksonomisindeki hatırlama ve anlama bilişsel düzeyleri açısından incelenmesi. Sosyal Bilimler Dergisi / Journal of Social Sciences, 37(1), 122-135.

Miles, M. B., \& Huberman, A. M. (1994). Qualitative data analysis: An expanded sourcebook: CA: Sage.

Oran, M., \& Karalı, M. A. (2019). Ortaokul 7. sınıf sosyal bilgiler ders kitabı değerlendirme sorunlarının Bloom taksonomisinde bilişsel alan basamaklarına göre incelenmesi. Uşak Üniversitesi Eğitim Araştırmaları Dergisi, 5(3), 88-104.

Sallabaş, M. E., \& Yılmaz, G. (2020). Türkçe ders kitabında bulunan metin altı sorularının yenilenmiş Bloom taksonomisine göre incelenmesi. Ana Dili Eğitimi Dergisi, 8(2), 586-596.

Sönmez, V. (2015). Program geliştirme öğretmen el kitabı. Ankara: Anı Yayıncılık.

Sülçevsi, İ., \& Sülçevsi, N. (2007). Türkçe 6. Priştine: Albas.

Şen, Ü. (2010). Yurt dışında yaşayan Türk çocuklarının ana dili eğitimine yönelik Millî Eğitim Bakanlığı bünyesinde yapılan çalışma ve uygulamalar. Zeitschrift für die Welt der Türken/Journal of World of Turks, 2(3), 239-253.

Tutkun, Ö. F., \& Okay, S. (2012). Bloom'un yenilenmiş taksonomisi üzerine genel bir bakış. Sakarya University Journal of Education, 1(3), 14-22.

Ulum, H., \& Taşkaya, S. M. (2019). İlkokul 2, 3 ve 4. sınıf Türkçe ders ve çalışma kitaplarında yer alan etkinliklerin yenilenmiş Bloom taksonomisine göre incelenmesi. Kastamonu Eğitim Dergisi, 27(1), 107-118. 
Yıldırım, A., \& Şimşek, H. (2016). Sosyal bilimlerde nitel araştırma yöntemleri. Ankara: Seçkin Yayıncılık. Yüksel, S. (2007). Bilişsel alan sınıflanmasında (Taksonomi) yeni gelişmeler ve sınıflamalar. Journal of Turkish Educational Sciences, 5(3), 479-509.

\section{Extended Summary}

Turkish education activities carried out in Kosovo should be evaluated within the field of Turkish education. An important element and the most important course material of the Turkish course is the Turkish course book. In the literature, there is no study examining the 6 . grade Turkish Textbook used in Kosovo. The aim of this study is to examine the 6. grade Turkish Textbook used in Kosovo in terms of the educational program outcomes and cognitive domain levels. The results to be obtained will contribute to the preparation process of the textbook.

The research was designed as a case study from qualitative research methods. During the data collection process, document analysis method was used in the study. The documents reviewed were the Kosovo Lower Secondary Education Sixth Grade Plan and Program and the 6. grade Turkish Textbook. The Revised Bloom Taxonomy was used in the analysis of the data. The formula of Miles and Huberman (1994) was used to ensure reliability in the coding process made according to the revised Bloom Taxonomy.

According to the findings, 18 of the 26 acquisitions predicted in the curriculum exist in the textbook, while the remaining eight do not. This situation shows that the textbook cannot adequately reflect the gains of the curriculum. In the sub-text questions, the lower level cognitive process steps are emphasized, and the factual knowledge is concentrated among the types of knowledge. According to this, in the cognitive processes dimension of the 6th grade Turkish Book subtext questions; $65 \%$ is at the remembering level, $26 \%$ is at the understanding level, $1 \%$ is at the application level, and $4 \%$ is at the evaluation level. The intensity of remembering and comprehension levels shows that there is an unbalanced distribution. Considering the distribution of the 6th grade Turkish Book sub-text questions in terms of types of knowledge, it is seen that $59 \%$ of the knowledge is used as factual knowledge, $16 \%$ conceptual knowledge, and 19\% metacognitive knowledge. Here, too, there is an uneven distribution. The density of factual knowledge stands out.

According to the literature data and the results obtained, the textbook is insufficient in terms of fulfilling the outcomes and in the balanced distribution of the cognitive domain steps. It is suggested in the context of the study to overcome these deficiencies in the book writing process and in new editions. Considering the results and the publications on the subject in the literature, some suggestions can be made for the experts who will be involved in the process of preparing Turkish textbooks in Kosovo: 
1. 6. grade Turkish Textbook and other textbooks to be designed/published must fully reflect the achievements of the current Turkish curriculum.

2. It should be taken into consideration that the 6. grade Turkish Textbook and other textbooks to be designed/published should reflect the cognitive domain steps of the subtext questions in a balanced way.

3. 6th grade Turkish Textbook and other textbooks to be designed/published, should be in a style that encourages the student to be more participatory and researcher in accordance with the understanding of the age. After the texts in the 6. grade Turkish Textbook, questions were created according to the $5 \mathrm{~W} 1 \mathrm{H}$ technique. Designing activities in different styles to attract students' attention; using visuals and establishing connections with current developments are neglected but important issues at this point.

\section{Araştırmacıların Katkı Oranı Beyanı}

$\mathrm{Bu}$ çalışmada giriş, kavramsal çerçeve, bulgular, sonuçlar ve tartışma bölümlerinin yazılmasında iki yazarın da katkıları olmuştur. İkinci yazar özellikle yöntem bölümünde verilerin toplanması ve analizi ve bulguların ortaya çıkarılması aşamalarında katkı sağlamıştır.

\section{Destek ve Teşekkür Beyanı}

$\mathrm{Bu}$ araştırmada herhangi bir kurum, kuruluş ya da kişiden destek alınmamıştır.

\section{Çatışma Beyanı}

Araştırmacının araştırma ile ilgili diğer kişi ve kurumlarla herhangi bir kişisel ve finansal çıkar çatışması yoktur.

\section{Etik Kurul Beyanı}

$\mathrm{Bu}$ araştırma doküman incelemesi yapılarak yürütüldüğünden etik kurul kararı gerektirmemektedir. 